\title{
Whole-lactation feed intake, milk yield, and energy balance of Holstein and Swedish Red dairy cows fed grass-clover silage and 2 levels of byproduct-based concentrate
}

\author{
Johanna Karlsson, ${ }^{1 *} \odot$ Mikaela Lindberg, ${ }^{1} \odot$ Maria Åkerlind, ${ }^{2} \odot$ and Kjell Holtenius ${ }^{1}$ () \\ ${ }^{1}$ Department of Animal Nutrition and Management, Swedish University of Agricultural Sciences, Box 7024, SE-750 07 Uppsala, Sweden \\ ${ }^{2}$ Växa Sverige, Box 7024, SE-750 07 Uppsala, Sweden
}

\begin{abstract}
Ruminants can produce meat and milk from fibrous feed and byproducts not suitable for human consumption. However, high-yielding dairy cows are generally fed a high proportion of cereal grain and pulses, which could be consumed directly by humans. If high production of dairy cows could be maintained with ingredients of low human interest, the sustainability of dairy production would improve. In the present study, 37 multiparous [Holstein $(\mathrm{n}=13)$ and Swedish Red $(\mathrm{n}=$ 24)] dairy cows were followed over a whole lactation. A low-concentrate diet of up to $6 \mathrm{~kg}$ concentrate per day (6kgConc) was fed to 27 cows, whereas 10 cows were fed a high-concentrate diet of up to $12 \mathrm{~kg}$ concentrate per day (12kgConc). The concentrate was mainly based on byproducts (sugar beet pulp, wheat bran, rapeseed meal, distiller's grain). Grass-clover silage of high digestibility was offered ad libitum. Over the whole lactation, cows on the $6 \mathrm{kgConc}$ diet had lower dry matter intake and higher forage intake than cows on the $12 \mathrm{kgConc}$ diet. Milk yield and energy balance were not influenced by dietary treatment. However, the cows on the $6 \mathrm{kgConc}$ diet numerically produced $2.4 \mathrm{~kg}$ less energy-corrected milk than cows on $12 \mathrm{kgConc}$ diet. The study lacked the statistical power to identify treatment effects on daily yield below $2.8 \mathrm{~kg}$ of milk due to low number of animals per treatment. Feed efficiency (as energy-corrected milk yield/dry matter intake or residual feed intake), body weight change, body condition change, milk fatty acid concentration in total milk fatty acids, plasma nonesterified fatty acids, glucose, $\beta$-hydroxybutyrate, and fertility measurements were not affected by diet, supporting the energy balance results. However, higher plasma concentrations of insulin-like growth factor-1 and insulin were observed in cows fed
\end{abstract}

Received January 15, 2020.

Accepted May 18, 2020

*Corresponding author: johanna.karlsson@slu.se the $12 \mathrm{kgConc}$ diet. These findings show that cows can adapt to a high-forage diet virtually without humangrade ingredients, without compromising feed efficiency or energy balance, thereby contributing to sustainable food production.

Key words: metabolic status, forage, coproduct, feed efficiency

\section{INTRODUCTION}

Increased food productivity, reduced postharvest losses, and reduced food waste are measures that have the potential to contribute strongly to increased food security, while at the same time mitigating climate change (IPCC, 2019). By converting byproducts from food and fuel systems and grass resources that are nonedible for humans into nutrient-dense foods such as milk and meat, animal production can help to reduce the environmental effect of food production (Van Zanten et al., 2019). Despite the astonishing ability of dairy cows to produce high-quality food from forage, their diet in conventional high-producing dairy systems worldwide contains a high share of cereal-based concentrate (FAO, 2014).

Replacing human-edible products such as cereal grain and pulses in dairy cow diets with byproducts such as sugar beet pulp, wheat bran, distiller's grain, and rapeseed meal is reported to have no negative effects on milk production in mid lactation (Ertl et al., 2016; Karlsson et al., 2018; Pang et al., 2018). Grass silage has relatively low production costs and high nutritive value for dairy cows if cut at an early growth stage (Randby et al., 2012). In addition, grass silage production and use in crop rotations contribute to several ecosystem services, such as improved soil quality, carbon sequestration, and control of pests and weeds (Weißhuhn et al., 2017).

Intake of diets with a large proportion of forage is normally limited by rumen fill factors (Jarrige et al., 1986). Thus, high-forage diets often lead to lower total DMI compared with high-concentrate diets (Faverdin 
et al., 1991; Randby et al., 2012; Lawrence et al., 2015). Lower dietary levels of concentrate may reduce the energy balance (EB) of dairy cows (Randby et al., 2012; Lawrence et al., 2015). A relationship between EB and milk fatty acid (FA) composition in both early and mid lactation has been reported (Gross et al., 2011). Some other indicators of impaired metabolic status are higher blood plasma concentrations of nonesterified fatty acids (NEFA) and BHB, along with lower concentrations of glucose, insulin, and IGF-1 in blood plasma (as reviewed by Adewuyi et al., 2005).

Deep negative EB in early lactation can contribute to impaired fertility (Wathes et al., 2007). Less concentrate in the diet of dairy cows is related to lower energy intake (Kuoppala et al., 2008; Randby et al., 2012) and lower EB (Randby et al., 2012; Lawrence et al., 2015). Thus, there may be a risk of lower levels of concentrate resulting in impaired fertility if energy intake is lower and negative EB more severe.

Numerous studies have explored high-forage diets to dairy cows, but these are usually limited to early or mid lactation, whereas whole-lactation experiments are more scarce. Therefore, the aim of the present study was to compare 2 levels of byproduct-based concentrate with ad libitum access to high-quality forage and the effects on production, EB, feed efficiency, and fertility during a whole lactation. The cows received either up to $6 \mathrm{~kg}$ (6 $\mathbf{k g C o n c})$ or $12 \mathrm{~kg}$ (12 $\mathbf{k g C o n c})$ of concentrate per day, in combination with grass-clover silage ad libitum. We hypothesized that cows receiving the $6 \mathrm{kgConc}$ diet would have lower DMI, resulting in less milk produced, compromised energy and metabolic status, and impaired fertility due to lower DM and energy intake compared with cows receiving the $12 \mathrm{kgConc}$ diet.

\section{MATERIALS AND METHODS}

The study was performed at the Swedish Livestock Research Centre, Uppsala, Sweden, between February 10, 2017, and May 12, 2018. The study was approved by Uppsala Ethics Committee for Animal Research, Uppsala, Sweden (diary number C99/16). The experiment was carried out in accordance with the laws and regulations controlling experiments performed with live animals in Sweden.

\section{Animals, Experimental Design, and Housing}

Forty-eight multiparous dairy cows were initially used. The cows were randomly allocated to 1 of 4 dietary treatments in a $2 \times 2$ factorial design. Fourteen cows were removed from the study due to subclinical mastitis caused by Staphylococcus aureus $(\mathrm{n}=7)$, or due to clinical mastitis by Klebsiella $(\mathrm{n}=2)$ or Esch- erichia coli $(\mathrm{n}=1)$, or due to mistakes in feeding $(\mathrm{n}=$ $2)$, teat injury $(\mathrm{n}=1)$, or stillborn calf $(\mathrm{n}=1)$. The cows with subclinical Staphylococcus aureus infection were removed from the study because they were moved to a separate pen to reduce the risk of spreading the infection. To somewhat balance the number of cows in each treatment group, 3 more cows were included later in the study. In the statistical analysis, 37 cows with whole-lactation records were included. All cows were multiparous (20 in second lactation, 17 older) and of the Swedish Red (SR; n = 24) or Swedish Holstein (n $=13$ ) breed. The cows calved between February and July 2017, entered the experiment during the first week after calving, and remained in the study until lactation day (mean \pm SD) $301 \pm 12$ (9 wk before expected calving or at 305 DIM).

The 4 dietary treatments were $6 \mathrm{kgConc}$ diet with rumen-protected amino acid-supplemented concentrate $(\mathrm{n}=14), 6 \mathrm{kgConc}$ diet without rumen-protected amino acid-supplemented concentrate $(\mathrm{n}=13), 12 \mathrm{kgConc}$ diet with rumen-protected amino acid-supplemented concentrate $(\mathrm{n}=5)$, and $12 \mathrm{kgConc}$ diet without rumenprotected amino acid-supplemented concentrate $(\mathrm{n}=$ $5)$. The numbers of cows allocated to each treatment were unbalanced due to a parallel genetics study on the $6 \mathrm{kgConc}$ diet cows. The effects of supplementing the diets with rumen-protected amino acids are not covered in this paper because the $\mathrm{CP}$ level in the silage and hence the total diet was not low enough to motivate the use or expect any effect of supplementation with rumen-protected lysine and methionine.

The cows were housed in a loose house with rubber mats and sawdust-bedded cubicles. The experimental cows were housed together with other cows, in a group of approximately 60 animals. Cows were milked voluntarily in a single-station automatic milking system (VMS, DeLaval International AB, Tumba, Sweden) with the FeedFirst cow traffic system, which resulted in 2.6 milkings per day $(\mathrm{SD}=0.4)$. Milking interval was set to $6 \mathrm{~h}$ for cows with low SCC and $4 \mathrm{~h}$ for cows with high SCC (over 100,000 cells/mL), both with a maximum of $12 \mathrm{~h}$ between milkings.

\section{Diets and Feeding}

Chemical composition of silage and concentrates is shown in Table 1. All cows had free access to grassclover silage from perennial swards sown mainly with timothy (Phleum pratense L.), with inclusion of perennial ryegrass (Lolium perenne L.), tall fescue (Festuca arundinacea Schreb.), and red clover (Trifolium pratense L.). The silage was stored in bunker silos and preserved using an acid-based additive (Promyr NT 570, Perstorp, Sweden) provided at 3.5 to $4.0 \mathrm{~L} / \mathrm{t}$. During the 
Table 1. Chemical composition (mean $\pm \mathrm{SD}$ ) of experimental feeds $(\mathrm{g} / \mathrm{kg} \text { of DM unless otherwise stated })^{1}$

\begin{tabular}{lcc}
\hline Item & $\begin{array}{c}\text { Grass-clover } \\
\text { silage }^{2}\end{array}$ & $\begin{array}{c}\text { Byproduct-based } \\
\text { concentrate }\end{array}$ \\
\hline $\mathrm{DM}(\mathrm{g} / \mathrm{kg})$ & $407 \pm 50$ & $872 \pm 8.4$ \\
$\mathrm{Ash}$ & $86.4 \pm 4.0$ & $65.4 \pm 4.8$ \\
$\mathrm{CP}$ & $166 \pm 17$ & $151 \pm 6.1$ \\
Crude fat & $-{ }_{3}$ & $47.8 \pm 6.1$ \\
$\mathrm{NDF}$ & $425 \pm 35$ & $361 \pm 10$ \\
$\mathrm{Starch}$ & - & $54.4 \pm 11$ \\
$\mathrm{WSC}^{4}$ & - & $5.3 \pm 1.7$ \\
$\mathrm{NE}_{\mathrm{L}}(\mathrm{MJ} / \mathrm{kg}$ of $\mathrm{DM})$ & $6.63 \pm 0.14$ & $6.64 \pm 0.05^{5}$ \\
$\mathrm{ME}(\mathrm{MJ} / \mathrm{kg}$ of $\mathrm{DM})$ & $11.6 \pm 0.3$ & $12.5^{6}$ \\
\hline
\end{tabular}

${ }^{1}$ Where SD is reported, the number of samples used for analyses of chemical composition was $n=31$ for silage and $n=32$ for concentrates, except for fat content where $\mathrm{n}=5$ for concentrates.

${ }^{2}$ Grass-clover silage had $\mathrm{pH} 4.24 \pm 0.14, \mathrm{NH}_{3}-\mathrm{N}$ concentration $36 \pm$ $10 \mathrm{~g} / \mathrm{kg} \mathrm{N}$, and estimated in vivo digestibility of OM in sheep fed at maintenance of $80.0 \pm 1.5 \%$ of OM.

${ }^{3}$ Not analyzed.

${ }^{4}$ Water-soluble carbohydrates.

${ }^{5}$ Calculated in NorFor (Åkerlind and Volden, 2011) based on chemical composition, and tabulated values and estimates where analytical data were lacking.

${ }^{6}$ Calculated based on concentrate formulation and tabulated values according to the Swedish Board of Agriculture (SJVFS, 2011).

course of the experiment, silage from 4 different bunker silos was used. A mineral mix containing $(\mathrm{g} / \mathrm{kg}) \mathrm{Ca}$ (164), P (10), Mg (120), Na (77), S (15), and trace elements and vitamins $(3.75 \mathrm{~g} / \mathrm{kg}$ of DM; VM17, Vilomix, Staffanstorp, Sweden) was mixed with the silage. In addition, $\mathrm{NaCl}$ was mixed with the silage at $3.75 \mathrm{~g} / \mathrm{kg}$ of $\mathrm{DM}$. Minerals and $\mathrm{NaCl}$ were mixed with the silage in a stationary vertical mixer before being distributed into the forage troughs.

The 2 concentrates were pelleted and largely based on byproducts of low human interest (Table 2). One concentrate was supplemented with rumen-protected lysine and methionine, whereas the other was not. The concentrates were fed individually in 4 concentrate dispensers (FSC400, DeLaval International AB), restricted to maximum $9 \mathrm{~kg} / \mathrm{d}$ ( $12 \mathrm{kgConc}$ diet) or $3 \mathrm{~kg} / \mathrm{d}$ ( $6 \mathrm{kgConc}$ diet). The daily concentrate ration was automatically distributed over several smaller portions, with the portion size set at maximum $2 \mathrm{~kg}$ and minimum $0.5 \mathrm{~kg}$. All cows were also offered up to $3 \mathrm{~kg} / \mathrm{d}$ of concentrate by dispensers in the milking station. Before calving, all cows were fed the concentrate without rumen-protected amino acids starting $2 \mathrm{wk}$ before expected calving. The concentrate ration before calving was increased by 0.5 $\mathrm{kg} / \mathrm{d}$ until $3 \mathrm{~kg} / \mathrm{d}$ was reached. The cows stayed on the $3 \mathrm{~kg} / \mathrm{d}$ concentrate ration until after calving, when they were moved to the group of milking cows. The concentrate ration was then increased over $21 \mathrm{~d}$ to a total concentrate ration of $12 \mathrm{~kg} / \mathrm{d}$ in the $12 \mathrm{kgConc}$ treatment and $6 \mathrm{~kg} / \mathrm{d}$ in the $6 \mathrm{kgConc}$ treatment. The
Table 2. Formulation of the byproduct-based concentrate $(\mathrm{g} / \mathrm{kg}$ of DM unless otherwise stated)

\begin{tabular}{lc}
\hline Ingredient & $\begin{array}{c}\text { Byproduct-based } \\
\text { concentrate }\end{array}$ \\
\hline Sugar beet pulp & \\
Wheat bran & 566 \\
Wheat flour $^{2}$ & 120 \\
Rapeseed meal $^{3}$ & 100 \\
Distillers grain $^{4}$ & 70.0 \\
Vegetable fat $^{5}$ & 70.0 \\
Molasses & 25.4 \\
Salt & 25.2 \\
Limestone & 10.7 \\
Rumen-protected lysine & 6 \\
Rumen-protected methionine & 7.40 \\
Premix $^{8}$ & $4.99 / 0$ \\
& $1.90 / 0$ \\
\hline
\end{tabular}

${ }^{1}$ Dried and unmolassed (Nordic Sugar AB, Eslöv, Sweden).

${ }^{2}$ Not food quality.

${ }^{3}$ Solvent-extracted and heat-moisture treated, with low levels of glucosinolates and erucic acid (ExPro, AAK Sweden AB, Karlshamn, Sweden).

${ }^{4}$ Fiber and yeast cells from ethanol manufacturing (Agrow Drank 90, Lantmännen Agroetanol, Norrköping, Sweden).

${ }^{5}$ Fatty acids (99\% fatty acids; 45\% C16:0, 37\% C18:1 according to manufacturer; Ako Feed Cattle, AAK Sweden AB, Karlshamn, Sweden).

${ }^{6}$ LysiPearl (Kemin, Herentals, Belgium). Added in the concentrate fed to half of the cows.

${ }^{7}$ MetaSmart Dry (Adisseo, Antony, France). Added in the concentrate fed to half of the cows.

${ }^{8}$ Containing minerals $(\mathrm{g} / \mathrm{kg})$ Ca $61.9, \mathrm{P}$ 0.4, Mg 408.9, K 1.0, Na 0.2, $\mathrm{S} 3.2$, vitamin A 2,000,030 IU, vitamin $\mathrm{D}_{3} 1,000,090 \mathrm{IU}$, and vitamin E 20,011 mg, and trace elements (mg/kg) Cu 5, Mn 10, Zn 25, I 0.35, Se 0.2 , and Co 0.09 .

cows stayed on that ration until 210 DIM, when the concentrate amount was gradually decreased to $0 \mathrm{~kg} / \mathrm{d}$ over $95 \mathrm{~d}$. For cows that had started dry-off before 305 DIM, the concentrate ration was decreased to $0 \mathrm{~kg}$ before drying off at $9 \mathrm{wk}$ before expected calving.

All cows had access to a small grass-covered permanent paddock for exercise and recreation at nighttime between mid-May to mid-August, in compliance with Swedish animal welfare law. All cows housed in the same area as the 37 experimental cows (in total approximately 60 cows) had access to 1 of 3 paddocks of 0.2 ha each. The cows were rotated between the 3 paddocks, changing paddock each day. Individual pasture intake, estimated to be $0.5 \mathrm{~kg}$ of $\mathrm{DM} / \mathrm{d}$, was not included in total DMI. The paddocks were mown when necessary to ensure low pasture intake.

\section{Measurements and Sample Collection}

Individual daily forage intake was recorded automatically by 20 forage troughs on weight scales (CRFI, BioControl Norway A/S, Rakkestad, Norway). Daily concentrate intake was recorded by dispensers (FSC400, DeLaval International $\mathrm{AB}$ ). The equipment used for 
forage intake recording was calibrated weekly and that used for concentrate intake recording was calibrated monthly. The individual daily forage intake raw data showed improbably high feed intake for some cows and days, caused by some cows that were throwing silage out of the forage troughs. Therefore intake for feeding occasions with intake rate $>8.28 \mathrm{~g} / \mathrm{s}$ of fresh weight (95\% confidence level of all eating occasions for all cows included in the study) was replaced with individual intake estimates derived from daily average intake rate $<8.28 \mathrm{~g} / \mathrm{s}$. Forage DMI and total DMI were treated as missing values for days when total DMI divided by metabolic BW was above $0.22 \mathrm{~kg} / \mathrm{kg}$ (95\% confidence level). The cows were automatically weighed every time they passed through a sorting gate when leaving the feeding area, and mean daily $\mathrm{BW}$ was recorded (AWS100, DeLaval International AB). Body condition score (scale of 1-5) was assessed automatically with a 3-D camera (DeLaval International AB) every time the cows left the milking station. Weekly mean BW and BCS were calculated from daily mean BW and BCS, respectively.

Silage was sampled 5 times a week and pooled into 3 -wk periods for analysis of chemical composition, whereas concentrates were sampled once a week and pooled into 4 -wk periods for the analysis. Silage samples were collected in plastic bags and stored at $-20^{\circ} \mathrm{C}$ until analysis, whereas concentrate samples were stored at room temperature in plastic bags. Spot samples of feces for estimation of digestibility were collected once a day on 3 consecutive days in early ( $23 \pm 5.5 \mathrm{DIM})$ and mid lactation (134 \pm 6.4 DIM) (Mehtiö et al., 2016). Feces sampling was done in the morning on the first and third sampling day, whereas the second sampling was done in the afternoon. The feces were stored at $-20^{\circ} \mathrm{C}$ until further processing.

At each milking, milk yield was recorded. Milk was sampled once a day twice weekly for progesterone $(\mathbf{P} \mathbf{4})$ analysis. All cows were sampled for P4 until confirmed pregnant. Milk sampling for milk composition was carried out every second week and then milk samples were taken at 2 consecutive milkings. The milk meter (MM25, DeLaval International AB) used for measuring milk yield and the milk sampler (DeLaval Milk Sampler, DeLaval International AB) have been certified by the International Committee for Animal Recording (Rome, Italy). Milk samples were preserved with bronopol, stored at $8^{\circ} \mathrm{C}$, and analyzed within $3 \mathrm{~d}$.

Blood samples were drawn from the coccygeal vein or artery of the tail-head in lactation wk 2,4 , and 6 , and once in lactation wk 19 to 21, into 10-mL vacuum tubes with lithium heparin as anticoagulant (BD Vacutainer, Becton, Dickinson and Company, Franklin Lakes, NJ). Either venous or arterial blood was used because the difference is negligible when drawn at the tail-head (Hristov et al., 2019). The blood samples were centrifuged immediately $\left(4,000 \times \mathrm{g}, 10 \mathrm{~min},+4^{\circ} \mathrm{C}\right)$ and the blood plasma was transferred to Eppendorf tubes and stored at $-20^{\circ} \mathrm{C}$ until analysis.

\section{Chemical Analysis and Calculations}

Analyses of feed, milk composition, feces, and blood plasma were performed by the laboratory at the Department of Animal Nutrition and Management, Swedish University of Agricultural Sciences (SLU), Uppsala, Sweden, unless otherwise stated. The DM content of silage was determined by first drying at $60^{\circ} \mathrm{C}$ overnight, milling, and then drying at $60^{\circ} \mathrm{C}$ overnight, according to Åkerlind et al. (2011). The DM content of concentrate feeds was determined by drying at $103^{\circ} \mathrm{C}$ overnight. Ash content in all feeds was determined by ignition at $550^{\circ} \mathrm{C}$ for $3 \mathrm{~h}$. Acid-insoluble ash (AIA) content in all feeds was analyzed according to Van Keulen and Young (1977). Feeds were analyzed for CP in an automated Kjeldahl procedure (Foss, Hillerød, Denmark). Ether extracts were analyzed by Eurofins Food \& Feed Testing Sweden AB, Jönköping, Sweden, according to EC (2009). Concentrate samples were analyzed enzymatically for starch (including maltodextrin) according to Larsson and Bengtsson (1983). All feeds were analyzed for NDF according to Chai and Udén (1998). Silage samples were pressed and the silage juice was analyzed for $\mathrm{pH}$. Metabolizable energy content in concentrates was calculated based on tabulated values according to the Swedish Board of Agriculture (SJVFS, 2011). Estimated in vivo digestible organic matter (OMD) content in silage was analyzed by the ruminal fluid digestible OM (VOS) method according to Lindgren $(1979,1983)$ as OMD in vivo $=0.90 \times \operatorname{VOS}-2$. Metabolizable energy content in silage was estimated according to Lindgren (1983) as ME (MJ/kg of OM) $=0.160 \times \operatorname{VOS}(\%)-1.91$. Metabolizable energy was then converted to $\mathrm{MJ} / \mathrm{kg}$ of DM.

Net energy content in the feed and energy intake were estimated according to the NorFor system (Volden and Nielsen, 2011). Energy balance and residual feed intake (RFI) were calculated as

$$
\begin{aligned}
\mathrm{EB}= & \left(\mathrm{NE}_{\text {intake }}\right)-\left(\mathrm{NE}_{\text {maintenance }}+\mathrm{NE}_{\text {milk }}\right) \\
\mathrm{RFI}= & \left(\mathrm{NE}_{\text {intake }}\right)-\left(\mathrm{NE}_{\text {maintenance }}+\mathrm{NE}_{\text {milk }}\right. \\
& \left.-\mathrm{NE}_{\text {mobilization }}+\mathrm{NE}_{\text {deposition }}\right)
\end{aligned}
$$

where $\mathrm{NE}_{\text {intake, }} \mathrm{NE}_{\text {maintenance, }} \mathrm{NE}_{\text {milk }}, \mathrm{NE}_{\text {mobilization, }}$ and $\mathrm{NE}_{\text {deposition }}$ were calculated according to the NorFor system (Volden and Nielsen, 2011). The nutrient intake 
per cow and week was calculated using mean values from the specific silo that the cows were fed that particular week, as silages from 4 different silos were used in the study.

Milk samples were analyzed for composition of fat, the 4 most abundant FA (C14:0, C16:0, C18:0, and C18:1 cis-9), and protein and lactose by infrared Fourier transform spectroscopy (CombiScope FTIR $300 \mathrm{HP}$, Delta Instruments B.V., Drachten, the Netherlands). The same instrument was used for analysis of SCC by flow cytometry. Lactose was corrected for lactase monohydrate by division by 1.053. Energy-corrected milk was calculated based on fat, protein, and lactose concentration according to Sjaunja et al. (1990). Because the cows were milked with different milking intervals in an automated milking system, daily estimates of ECM, milk component yields, and milk composition values were adjusted based on time since last milking. Milk samples were analyzed for P4 by Eurofins Milk Testing Sweden AB using an enzyme immunoassay method (ELISA M-plate, Ridgeway Science, St Briavels, UK). The P4 content was measured for each animal and profiles were classified according to Petersson et al. (2006) as normal or disturbed, with the limit for luteal activity set at a milk $\mathrm{P} 4$ concentration of $>5 \mathrm{ng} /$ $\mathrm{mL}$. Days from calving to last insemination, days from calving to commencement of luteal activity (CoLA), days from calving to first ovulation, days from calving to next calving, and total number of inseminations were recorded. Each animal was categorized as early $(<23$ d) or late $(\geq 23 \mathrm{~d})$ for CoLA and whether pregnant at first AI or not.

Feces samples were freeze-dried, milled, and analyzed for DM, ash, and AIA. The total amount of feces was calculated from the total intake of AIA and the content of AIA in the feces (Van Keulen and Young, 1977). Total-tract apparent OMD was calculated from estimated intake and excretion of $\mathrm{OM}$ from feed and feces, as $\left(\mathrm{OM}_{\text {intake }}-\mathrm{OM}_{\text {feces }}\right) / \mathrm{OM}_{\text {feed }}$. The calculation was based on feces samples taken once daily on 3 consecutive days and intake data from the 3 feces sampling days and the previous day.

Blood plasma was analyzed for metabolites and hormones. Glucose concentration was analyzed enzymatically (D-Glucose UV-method, R-Biopharm AG, Darmstadt, Germany). Insulin concentration was analyzed using an enzyme immunoassay method adapted for bovines (Mercodia Bovine Insulin ELISA, Mercodia AB, Uppsala, Sweden), and the concentration of NEFA using an enzymatic colorimetric method (NEFA-HR, Fujifilm Wako Diagnostics U.S.A. Corporation, Mountain View, CA). The concentration of BHB in plasma was analyzed with a colorimetric test (MAK041, Sigma-Aldrich, St. Louis, MO), whereas the IGF-1 con- centration was analyzed with an enzyme immunoassay (Mediagnost E20, Mediagnost, Reutlingen, Germany).

\section{Statistical Analyses}

All statistical analyses were performed in SAS software (version 9.4, SAS Institute Inc., Cary, NC). Treatment effects of feed and nutrient intake, milk yield and composition, BCS and BW variables, and blood plasma variables were analyzed using the PROC MIXED, with lactation week repeated autoregressively:

$$
\begin{aligned}
\mathrm{Y}_{\mathrm{ijklmnp}}=\mu & +\mathrm{C}_{\mathrm{i}}+\mathrm{P}_{\mathrm{j}}+\mathrm{B}_{\mathrm{k}}+\mathrm{L}_{\mathrm{l}}+\mathrm{T}_{\mathrm{m}}+\mathrm{W}_{\mathrm{n}}+\mathrm{E}_{\mathrm{p}} \\
& +\mathrm{LW}_{\mathrm{ln}}+\mathrm{BL}_{\mathrm{kl}}+\varepsilon_{\mathrm{ijklmnp}},
\end{aligned}
$$

where $Y_{\mathrm{ijklmn}}$ is the dependent variable, $\mu$ is the overall mean, $\mathrm{C}_{\mathrm{i}}$ is the random effect of cow $\mathrm{i}, \mathrm{P}_{\mathrm{j}}$ is the effect of parity $\mathrm{j}, \mathrm{B}_{\mathrm{k}}$ is the effect of breed $\mathrm{k}, \mathrm{L}_{\mathrm{l}}$ is the effect of concentrate level $l, T_{m}$ is the effect of concentrate type $\mathrm{m}, \mathrm{W}_{\mathrm{n}}$ is the effect of lactation week $\mathrm{n}, \mathrm{E}_{\mathrm{p}}$ is the effect of ECM in previous lactation $\mathrm{p}, \mathrm{LW}_{\mathrm{ln}}$ is the concentrate level $\times$ lactation week interaction effect of concentrate level 1 and lactation week $\mathrm{n}, \mathrm{BL}_{\mathrm{kl}}$ is the breed $\times$ concentrate level interaction effect of breed $\mathrm{k}$ and concentrate level 1 , and $\varepsilon_{\mathrm{ijklmn}}$ is the random error. Multiparous cows in parity 3 and older formed one parity class and all cows in their second parity formed another parity class. For treatment effects of digestibility (with only 2 measures per cow), the model was adapted in that cow was not treated as a random effect and lactation week was repeated unstructured.

Treatment effects on weekly change in BCS and BW were analyzed by PROC GLM with the following model:

$\mathrm{Y}_{\mathrm{ijklmn}}=\mu+\mathrm{C}_{\mathrm{i}}+\mathrm{P}_{\mathrm{j}}+\mathrm{B}_{\mathrm{k}}+\mathrm{L}_{\mathrm{l}}+\mathrm{T}_{\mathrm{m}}+\mathrm{W}_{\mathrm{n}}+\varepsilon_{\mathrm{ijklmn}}$,

where $Y_{\mathrm{ijklmn}}$ is the dependent variable, $\mu$ is the overall mean, $C_{i}$ is the random effect of cow $i, P_{j}$ is the effect of parity $j, B_{k}$ is the effect of breed $k, L_{l}$ is the effect of concentrate level $l, T_{m}$ is the effect of concentrate type $\mathrm{m}, \mathrm{W}_{\mathrm{n}}$ is the effect of lactation week $\mathrm{n}$, and $\varepsilon_{\mathrm{ijklmn}}$ is the random error.

Treatment effects of binary fertility data were analyzed by PROC LOGISTIC with the following model:

$$
\mathrm{Y}_{\mathrm{ijklm}}=\mu+\mathrm{C}_{\mathrm{i}}+\mathrm{P}_{\mathrm{j}}+\mathrm{B}_{\mathrm{k}}+\mathrm{L}_{\mathrm{l}}+\mathrm{T}_{\mathrm{m}}+\varepsilon_{\mathrm{ijklm}},
$$

where $Y_{\mathrm{ijklm}}$ is the dependent variable, $\mu$ is the overall mean, $C_{i}$ is the random effect of cow $i, P_{j}$ is the effect of parity $j, B_{k}$ is the effect of breed $k, L_{l}$ is the effect of concentrate level $l, T_{m}$ is the effect of concentrate type $\mathrm{m}$, and $\varepsilon_{\mathrm{ijklm}}$ is the random error. 
Table 3. Feed intake during lactation wk 1 to 42 and apparent total-tract digestibility of DM (DMD) and OM (OMD) in early and mid lactation, presented as LSM with SEM and $P$-value of multiparous dairy cows fed a daily ration of up to $6 \mathrm{~kg}$ of concentrate (6kgConc) or up to $12 \mathrm{~kg}$ of concentrate (12kgConc), and of Holstein or Swedish Red (SR) breed

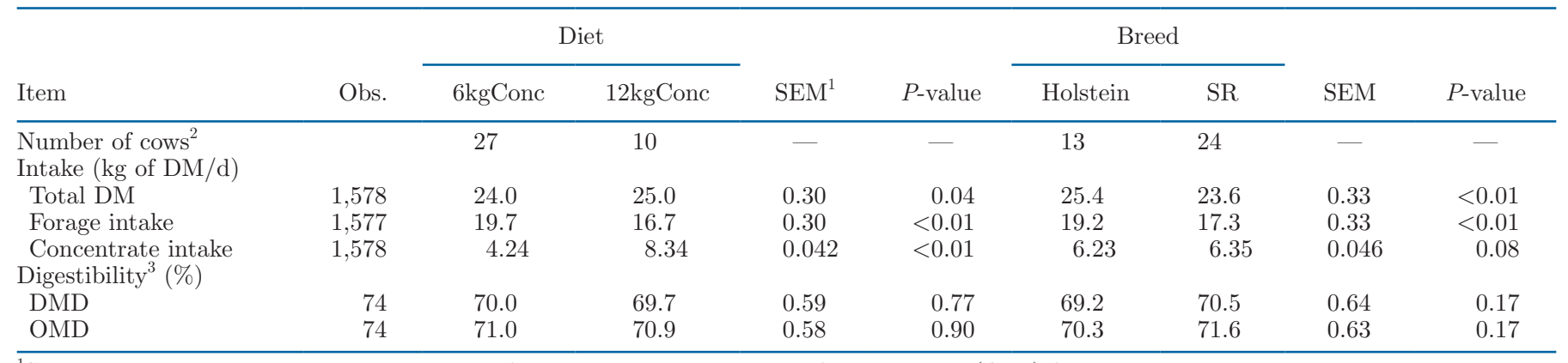

${ }^{1}$ SEM values are weighted averages to adjust for the unbalanced number of observations (Obs.) for the 2 treatment diets.

${ }^{2}$ The numbers of animals were unbalanced due to a parallel genetic study on the low-concentrate cows.

${ }^{3}$ Total-tract apparent digestibility determined from a pooled sample per cow and period, using fecal grab samples taken once daily on 3 consecutive days per period.

Correlations between EB and milk FA were analyzed by PROC CORR and expressed by the Pearson correlation coefficient $\left(\mathrm{r}_{\mathrm{xy}}\right)$.

Several models were tested to combine and account for interactions between variables. The models with the lowest Akaike information criterion were used. All residuals were tested for normality and log-transformation was applied to those that did not follow a normal distribution. Values presented in the text and tables are least squares means calculated using the LSMEANS/ PDIFF option. Statistically significant differences were determined following Tukey's adjustment declared at $P$ $\leq 0.05$, with trends noted at $P \leq 0.10$.

\section{RESULTS AND DISCUSSION}

We investigated the effects on performance, metabolic status, and feed efficiency traits in multiparous dairy cows of the breeds Holstein and SR of receiving up to 6 or $12 \mathrm{~kg}$ of byproduct-based concentrate per day in combination with high-quality grass-clover silage ad libitum over a whole lactation.

\section{Feed Intake}

The cows received up to 6 or $12 \mathrm{~kg}$ concentrate per day, which resulted in a daily mean concentrate intake of 4.24 and $8.34 \mathrm{~kg}$ of DM, respectively. Over the whole lactation, the $6 \mathrm{kgConc}$ cows consumed on average $83 \%$ forage (DM basis), whereas the corresponding value for the $12 \mathrm{kgConc}$ cows was $68 \%$ forage. Both diets can be considered high-forage diets compared with the typical diet of Swedish dairy cows (Emanuelson et al., 2006; Swensson et al., 2017) and dairy cows in other intensive nongrazing production systems (FAO, 2014). Cows offered the $6 \mathrm{kgConc}$ diet had higher forage intake, but did not manage to fully replace the lower concentrate ration with forage, and thus total DMI was lower for cows on the $6 \mathrm{kgConc}$ diet than for cows offered the $12 \mathrm{kgConc}$ diet (Table 3).

We found no difference in total-tract apparent digestibility in DM or OM between diets or breeds. The gold standard of estimating nutrient digestibility is total collection of feces. However, since both laborious and usually constraining the animals being sampled, spot sampling with markers such as AIA or iNDF are commonly used instead (Van Keulen and Young, 1977; Mehtiö et al., 2016; Morris et al., 2018). Diurnal variation of AIA is much less in diets based on alfalfa silage and byproducts compared with starch-rich corn silage-based diets (Morris et al., 2018), and diets based on grass have a higher content of AIA than alfalfa and concentrates (Van Soest, 1994), which is why AIA is likely a reliable marker in grass-rich diets. Morris et al. (2018) found no difference in fecal OM (\% of DM) between sampling every $2,4,6$, or $12 \mathrm{~h}$ in dairy cows fed a diet based on alfalfa silage and byproducts using AIA as a marker. However, AIA have been found to underestimate apparent $\mathrm{OM}$ digestibility (Morris et al., 2018), which is why the values in the present study (Table 3) might be somewhat low considering the high digestibility of the grass-clover silage used (Table 1).

The reduction in forage intake for cows on the $12 \mathrm{kgConc}$ diet compared with the $6 \mathrm{kgConc}$ diet was $2.7 \mathrm{~kg}$ of $\mathrm{DM} /$ cow per $\mathrm{d}$, whereas the increase in concentrate intake was $4.0 \mathrm{~kg}$ of $\mathrm{DM} /$ cow per $\mathrm{d}$. The substitution rate observed, of $0.68 \mathrm{~kg}$ of DM forage $/ \mathrm{kg}$ of DM concentrate, was similar to that in one earlier study (Kuoppala et al., 2008), lower than that in some studies (Randby et al., 2012; Patel et al., 2017), and higher than that in others (Agnew et al., 1996; Ferris et al., 2001; Lawrence et al., 2015), all with similar 
concentrate levels. Forage has a higher rumen fill value than concentrate (Volden and Nielsen, 2011), so cows usually cannot replace $1 \mathrm{~kg}$ of DM of concentrate with $1 \mathrm{~kg}$ of DM of forage. The concentrate substitution rate also seems to depend on the chemical composition and digestibility of both forage and concentrate. High energy value and high digestibility of silage allow greater total DMI with low-concentrate diets (Ferris et al., 2001). The silage used in the present study had a high energy value and high digestibility, which can at least partly explain the reasonably high substitution rate. On the other hand, the concentrate was based mainly on sugar beet pulp, which generally has a high content of soluble fiber, and not starch, which can decrease the substitution rate (Huhtanen, 1993; Huhtanen et al., 1995), although that is not always the case (Karlsson et al., 2018).

Forage intake, and thereby also total DMI, were relatively high in the present study (Ferris et al., 2001; Lawrence et al., 2015; Patel et al., 2017). However, others also have reported high intake levels with highdigestibility grass silages and concentrate rations of 8 to $12 \mathrm{~kg}$ (Kuoppala et al., 2008; Randby et al., 2012). The fact that only multiparous cows with high BW were included in the present study probably also contributed to the high DMI. Furthermore, the cows in the present study had a lower DMI per kilogram of BW than reported by Kuoppala et al. (2008) and Randby et al. (2012).

Holstein cows consumed more forage and had higher total DMI than SR cows, confirming previous findings (Li et al., 2018). A contributing factor enabling Holstein cows to consume more could be their size, as Holstein cows are larger and therefore probably have a larger digestion volume (Beecher et al., 2014).

\section{Milk Yield and Composition}

We found no statistical difference in milk and ECM yield between the 2 dietary treatments or between the 2 breeds (Table 4). This is in line with findings by Aguerre et al. (2011), although others have observed higher milk and ECM yield with higher concentrate rations (Andersen et al., 2003; Kuoppala et al., 2008; Randby et al., 2012), along with higher energy intake. Cows fed $12 \mathrm{kgConc}$ had higher energy intake than cows fed $6 \mathrm{kgConc}$ (Table 5), but milk yields were only numerically higher in $12 \mathrm{kgConc}$ cows. However, the present study lacked the statistical power to identify treatment effects on daily yield below $2.8 \mathrm{~kg}$ of milk. Higher production in Holstein cows compared with SR cows was expected (Li et al., 2018; Växa Sverige, 2018), but not observed. This might be explained by too few animals being included in the present study $(\mathrm{n}=37)$, in combination with the study design. We found no difference between the diets concerning feed efficiency as ECM/DMI (Table 5). This confirms findings by others comparing different forage:concentrate ratios (Kouppala et al., 2008; Aguerre et al., 2011; Randby et al., 2012).

The numerical difference between the diets of approximately $3.6 \mathrm{~kg}$ of ECM already at first milk sampling (Figure 1) was unexpected so early in lactation before any dietary treatment effect could have had any effect. In addition, BW tended to be higher in cows fed the $12 \mathrm{kgConc}$ diet, which could have been related to the numerical differences in milk yield already at first milk sampling. This would probably have been avoided if the treatment groups had been balanced with regard to milk yield in previous lactation and parity class. With the statistical model and design used in the present study we only detected differences in ECM between treatments in lactation wk 14. In late lactation, not even a numerical difference was present in ECM between the treatments (Figure 1). The ECM production rate seemed to decrease more rapidly for $12 \mathrm{kgConc}$ cows after lactation wk 30 and for $6 \mathrm{kgConc}$ cows after lactation wk 34. Based on the Strandberg correction (Strandberg and Lundberg, 1991), which corrects for the effect of pregnancy on milk yield based on days open, it is estimated that the effect on ECM yields starts at $160 \mathrm{~d}$ after conception. However, that might not be the explanation for the steeper lactation curves in late lactation in the present study because these cows reached $160 \mathrm{~d}$ after conception approximately 4 wk after the drop in ECM production. It is more likely that the reduction in concentrate offered initiated a more pronounced reduction rate in ECM yield at the end of lactation.

We found no difference in milk yield or in concentration of fat, protein, or lactose in milk between the $12 \mathrm{kgConc}$ and $6 \mathrm{kgConc}$ cows. However, cows on the $6 \mathrm{kgConc}$ diet had a tendency for lower milk fat yield (Table 4). Milk from SR cows generally has higher concentrations of fat and protein than milk from Holstein cows (Andrée O'Hara et al., 2018; Växa Sverige, 2018), a tendency also observed in the present study.

The most abundant FA in milk samples were analyzed (Table 4). Some of these milk FA can be used to indicate cow EB (Gross et al., 2011), as <C14:0 and to some extent also C16:0 in milk originate from mammary de novo synthesis of FA (Palmquist et al., 1969), whereas C18:0 and C18:1 cis-9 are preformed FA released from adipose tissue (Rukkwamsuk et al., 2000). No differences were observed in the concentrations of these milk FA in total milk fat ( $\mathrm{g}$ of FA/100 g of milk FA) between breeds or cows fed the $6 \mathrm{kgConc}$ and $12 \mathrm{kgConc}$ diets (Figure 2). However, $12 \mathrm{kgConc}$ cows 
Table 4. Milk performance during lactation wk 1 to 42 of multiparous dairy cows fed a daily ration of up to $6 \mathrm{~kg}$ of concentrate (6kgConc) or up to $12 \mathrm{~kg}$ of concentrate (12kgConc), and of Holstein or Swedish Red (SR) breed, presented as LSM with SEM and $P$-value

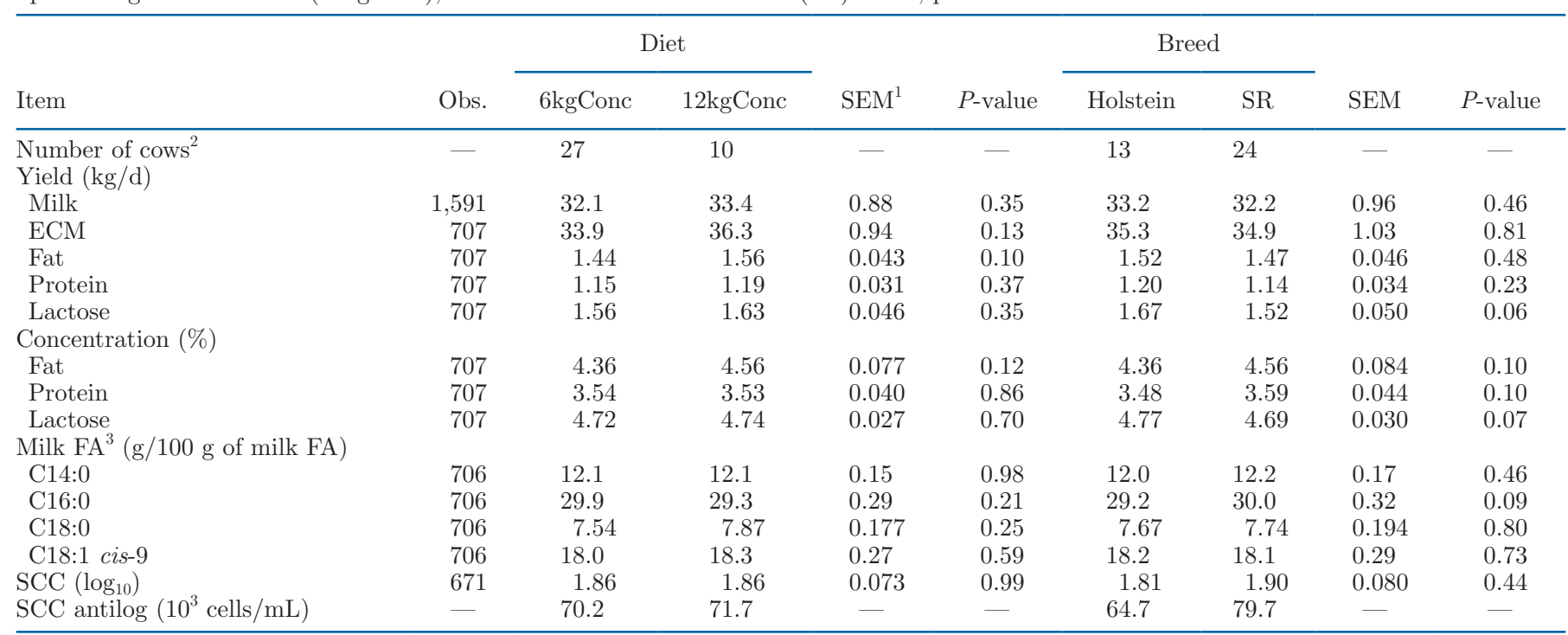

${ }^{1}$ SEM values are weighted averages to adjust for the unbalanced number of observations (Obs.) for the 2 treatment diets.

${ }^{2}$ The numbers of animals were unbalanced due to a parallel genetic study on the low-concentrate cows.

${ }^{3} \mathrm{FA}=$ fatty acid.

had an overall higher concentration of $\mathrm{C} 18: 0(P=0.05)$ and $\mathrm{C} 18: 1$ cis-9 $(P=0.05)$ in milk than $6 \mathrm{kgConc}$ cows. Results indicate that milk FA per $100 \mathrm{~g}$ of milk, where the effect of both milk fat concentration and milk FA concentration in milk fat are integrated, is a better estimator of negative EB than milk FA per $100 \mathrm{~g}$ of milk FA in lactation wk 2 to 6 (M. Churakov, SLU, Uppsala, Sweden, personal communication). If that is true, then our results suggest that cows on the $12 \mathrm{kgConc}$ diet mo- bilized more body fat to support milk production than cows on the $6 \mathrm{kgConc}$ diet, even though no differences were observed in EB calculated from milk yield and feed intake (Figure 3).

Over the lactation, milk FA concentrations varied (Figure 2). The C18:0 and C18:1 cis-9 (g of milk FA/100 $\mathrm{g}$ of milk) were negatively correlated $\left(\mathrm{r}_{\mathrm{xy}}=\right.$ -0.70 and -0.75 , respectively; $P<0.01$ ) with EB in lactation wk 2 to 18 , when cows overall were in negative

Table 5. Energy intake, energy balance (EB), residual feed intake (RFI), feed conversion, N efficiency, BCS, and BW, and their weekly change, during lactation wk 1 to 42 of multiparous dairy cows fed a daily ration of up to $6 \mathrm{~kg}$ of concentrate (6kgConc) or up to $12 \mathrm{~kg}$ of concentrate (12kgConc), and of Holstein or Swedish Red (SR) breed, presented as LSM with SEM and $P$-value

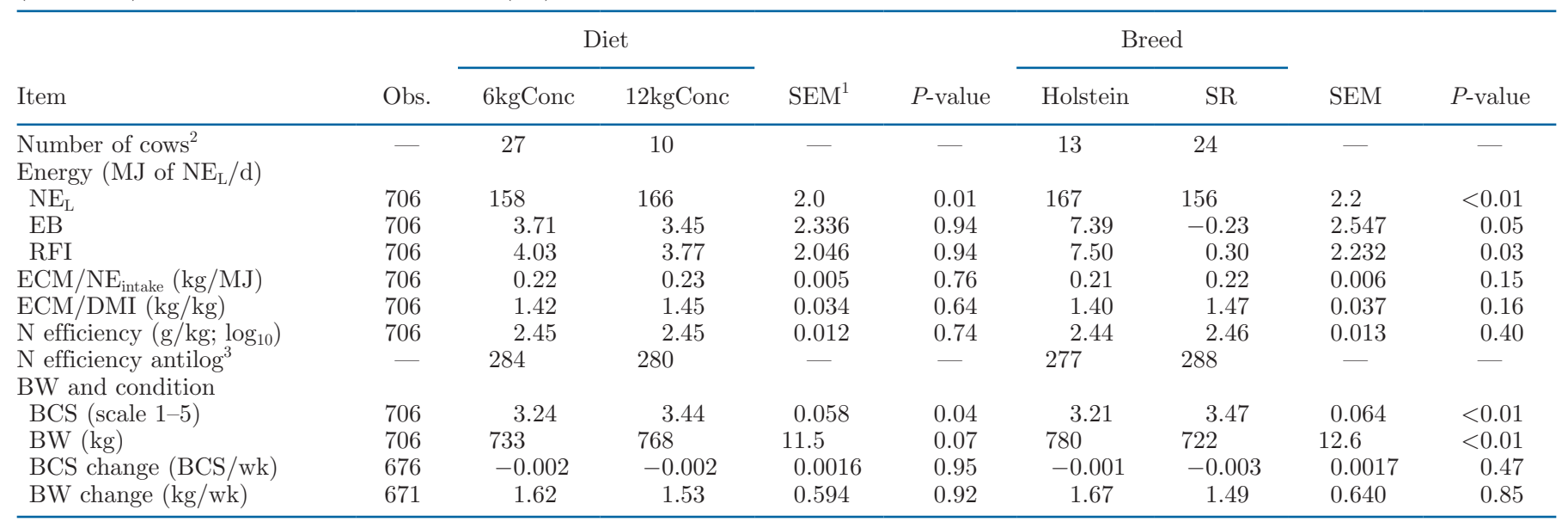

${ }^{1}$ SEM values are weighted averages to adjust for the unbalanced number of observations (Obs.) for the 2 treatment diets.

${ }^{2}$ The numbers of animals were unbalanced due to a parallel genetic study on the low-concentrate cows.

${ }^{3}$ Nitrogen efficiency $=($ milk protein yield $/ 6.38) /(\mathrm{CP}$ intake $/ 6.25)$. 
or weakly positive $\mathrm{EB}\left(<5 \mathrm{MJ}\right.$ of $\left.\mathrm{NE}_{\mathrm{L}} / \mathrm{d}\right)$. However, it is important to remember that these correlations only apply to this specific experiment with 2 quite similar diets and a relatively small number of cows that were all in their second lactation or older. Moreover, the concentrations of C14:0 and C16:0 in milk started increasing already after lactation wk 6 (g of milk FA/100 $\mathrm{g}$ of milk), just after peak lactation (Figure 1), and thus did not seem to be related to EB. The concentration changes in C16:0, and to some extent also of C14:0, in milk FA thus seemed to level out at the same time as EB became positive, around lactation wk 14 .

Apart from negative EB, effects in the rumen such as biohydrogenation and bacterial influence and diet composition can be reflected in milk FA profiles (Stoop et al., 2009; e.g., through forage:concentrate ratio). Reports indicate increased concentrations (g of FA/100 $\mathrm{g}$ of milk FA) of C16:0 (Soita et al., 2005; Neveu et al., 2013; Patel et al., 2013) and C18:1 cis-9 (Soita et al., 2005; Neveu et al., 2013) in milk with increasing proportion of forage. The lack of effect of forage: concentrate ratio on milk FA composition in the present study might be related to the low starch and high NDF content of the concentrate, as other studies have used grain-based concentrates.

\section{Blood Metabolites and Hormones}

Cows receiving the $12 \mathrm{kgConc}$ diet had overall higher concentrations of the hormones insulin and IGF-1 in the blood at lactation wk 2, 4, 6, and 20 than cows fed the $6 \mathrm{kgConc}$ diet, but we observed no effect of diet on the blood metabolites glucose, NEFA, and BHB (Table 6). For blood insulin concentrations, the difference between $6 \mathrm{kgConc}$ and $12 \mathrm{kgConc}$ cows was most pronounced for samples taken during lactation wk 6 (Figure 4). We found similar results for IGF-1 concentrations in the blood, with the most pronounced difference between dietary treatments in lactation wk 4 and 6. In studies comparing diets with high and low-concentrate rations for dairy cows in early lactation, the results concerning blood plasma biomarkers are somewhat conflicting, with some reporting higher BHB, lower glucose and insulin, and no effect on NEFA (Andersen et al., 2004) and others reporting lower BHB, higher NEFA, and no effect on glucose (Lawrence et al., 2015) for cows fed a low-concentrate diet. However, it is difficult to compare results from different studies because dietary regimens can vary substantially, as can their effect on EB. The lack of treatment effects on blood metabolites in the present study supports our finding that EB was not affected by concentrate diet. The higher energy intake for $12 \mathrm{kgConc}$ cows compared with $6 \mathrm{kgConc}$ cows could explain the higher concentrations of insulin and IGF1. Higher insulin concentrations may be an effect of more propionate being produced in cows fed more concentrate (Bines and Hart, 1984). The similar patterns of blood plasma concentrations of insulin and IGF-1 could be explained by insulin restoring growth hormone responsiveness, thereby recoupling the growth hormone-IGF axis (Butler et al., 2003).

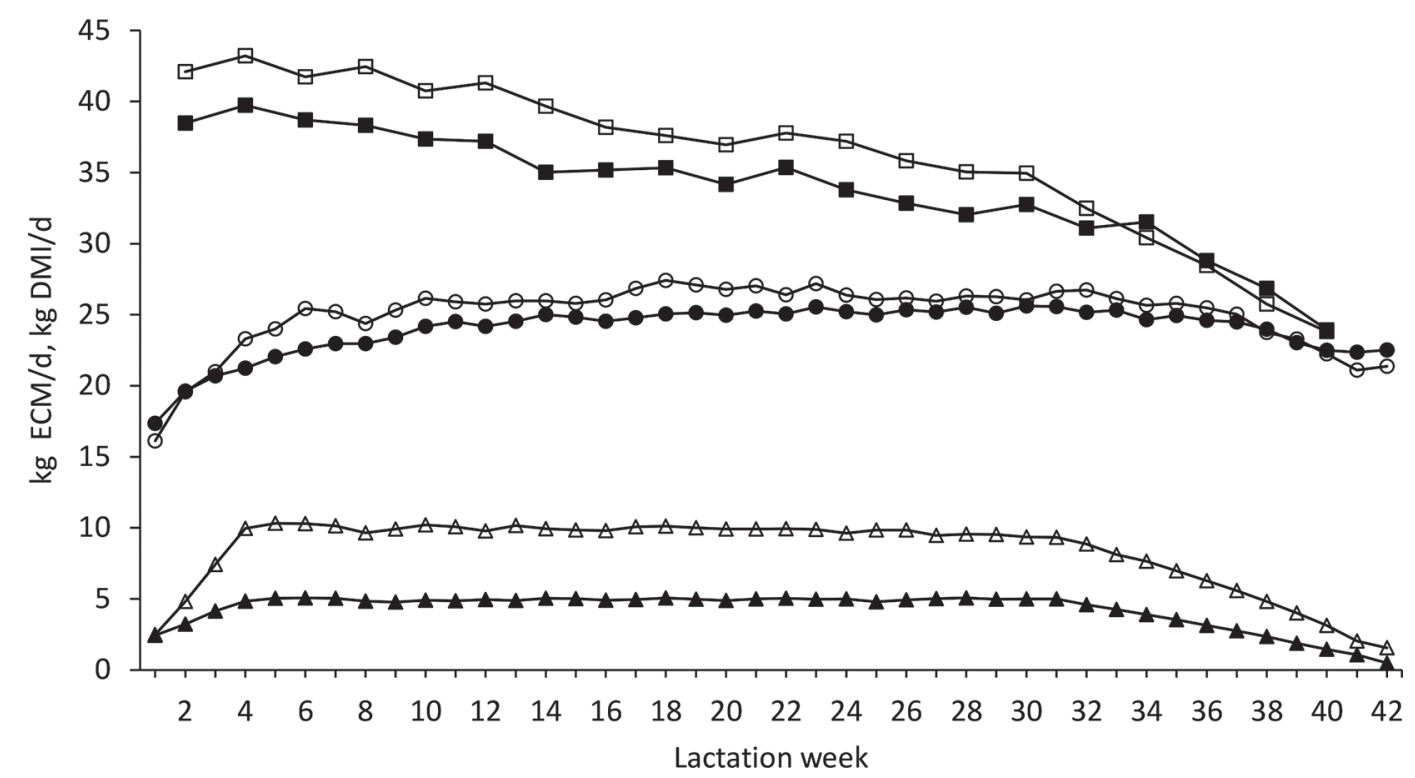

Figure 1. Energy-corrected milk yield (kg/d; squares), total DMI ( $\mathrm{kg} / \mathrm{d}$; circles), and concentrate DMI (kg/d; triangles), as LSM, per lactation week for multiparous cows fed a daily ration of up to $6 \mathrm{~kg}$ of concentrate (filled; $\mathrm{n}=27$ ) or up to $12 \mathrm{~kg}$ of concentrate (open; $\mathrm{n}=10$ ). The concentrate was byproduct based and fed together with high-quality forage ad libitum. 


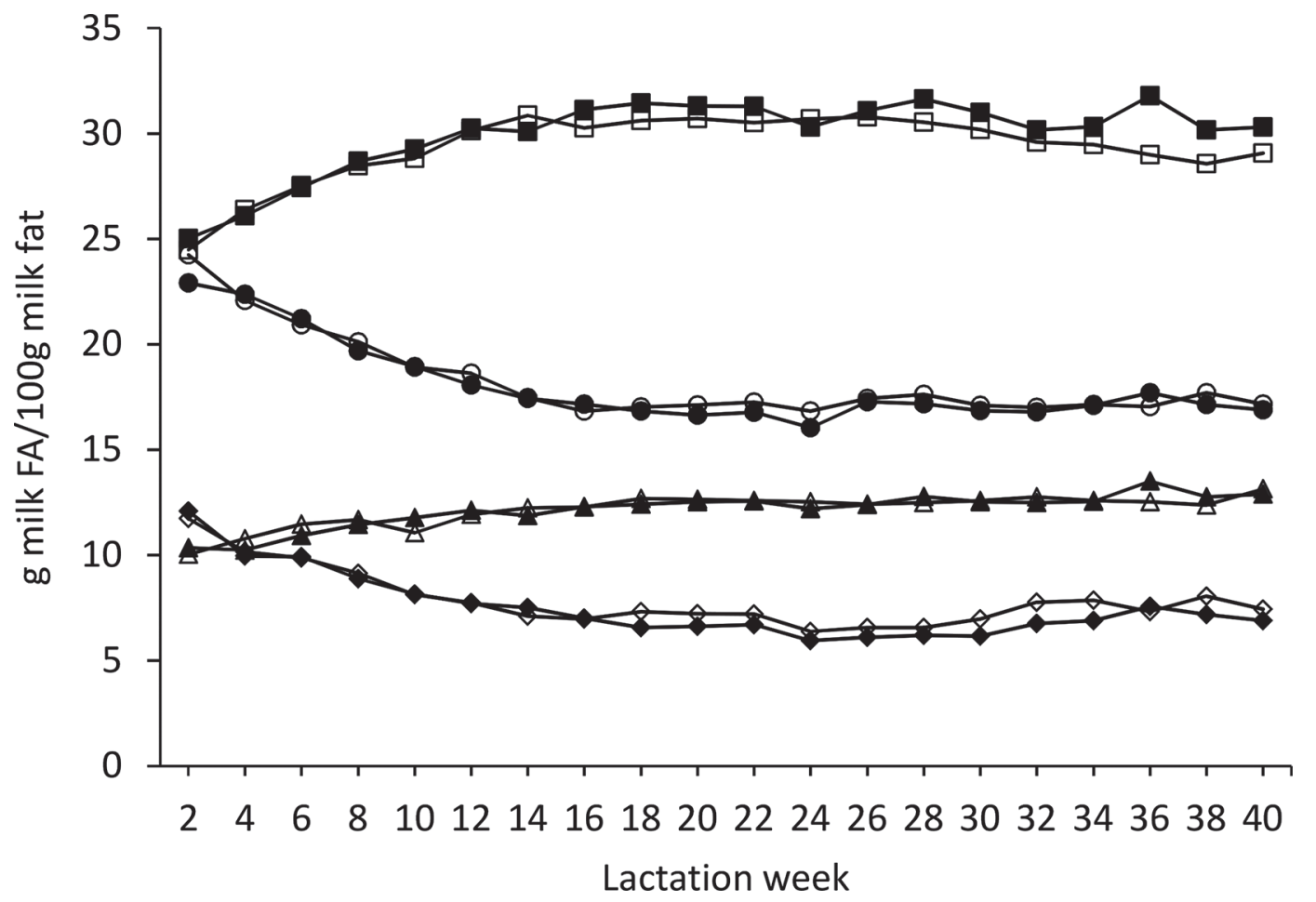

Figure 2. Concentrations of fatty acids (FA) of type C14:0 (triangles), C16:0 (squares), C18:0 (diamonds), and C18:1 cis-9 (circles) in milk fat ( $\mathrm{g}$ of FA/100 $\mathrm{g}$ of milk FA), presented as LSM, per lactation week for multiparous cows fed a daily ration of up to $6 \mathrm{~kg}$ of concentrate (filled; $\mathrm{n}=27$ ) or up to $12 \mathrm{~kg}$ of concentrate (open; $\mathrm{n}=10$ ). The concentrate was byproduct based and fed together with high-quality forage ad libitum. No difference was observed between diets for these 4 milk FA.

Holstein cows had overall higher blood concentrations of insulin, lower concentrations of NEFA, and higher energy intake than SR cows, whereas previous studies have found higher insulin concentrations in SR cows compared with Holstein cows (Nyman et al., 2008; Andrée O'Hara et al., 2019). It is unclear whether this is a pure breed effect or an indirect effect related to, for example, feed intake or body condition.

\section{Energy Balance, Body Weight, Body Condition Score, and Feed Efficiency}

We observed no overall effect or difference per lactation week on EB between diets (Figure 3), as indicated by the concentrations of blood metabolites. Other studies comparing different forage:concentrate ratios in early or mid lactation have found that EB is less negative in cows offered more concentrate (Randby et al., 2012; Lawrence et al., 2015). However, those studies had a greater difference in daily energy intake between dietary treatments than the present study. Holstein cows had a more positive overall EB than SR cows in the present study. In contrast, when Ntallaris et al. (2017) fed Holstein and SR cows at high or low feeding intensity until 120 DIM, Holstein cows tended to have a less positive EB than SR cows. The Holstein cows in the present study had a more positive EB also during the first 120 DIM, so it is more likely that the difference in results between the studies is because Ntallaris et al. (2017) only included primiparous cows and we only included multiparous cows, rather than being caused by different lactation stages.

In the present study, the cows returned to positive EB in lactation wk 14 for both concentrate levels, which is later than previously reported for diets with comparable grass silage quality in combination with 4 , 8 , or $12 \mathrm{~kg}$ of concentrate (Randby et al., 2012). The longer time taken to reach positive EB in the present study can be explained by higher ECM yield than in the study by Randby et al. (2012), as the cows in both studies had comparable energy intake levels.

We found no effect of diet or breed on weekly change in BW or BCS (Table 5). In contrast, most others have found that increasing levels of concentrate led to greater BW gain (Andersen et al., 2003; Kuoppala et al., 2004; Randby et al., 2012), and sometimes a greater increase in BCS (Lawrence et al., 2015). Changes in BW, but especially changes in BCS, reflect the EB of cows (Thorup et al., 2012), which was also observed as the lack of effect of diet in the present study on 


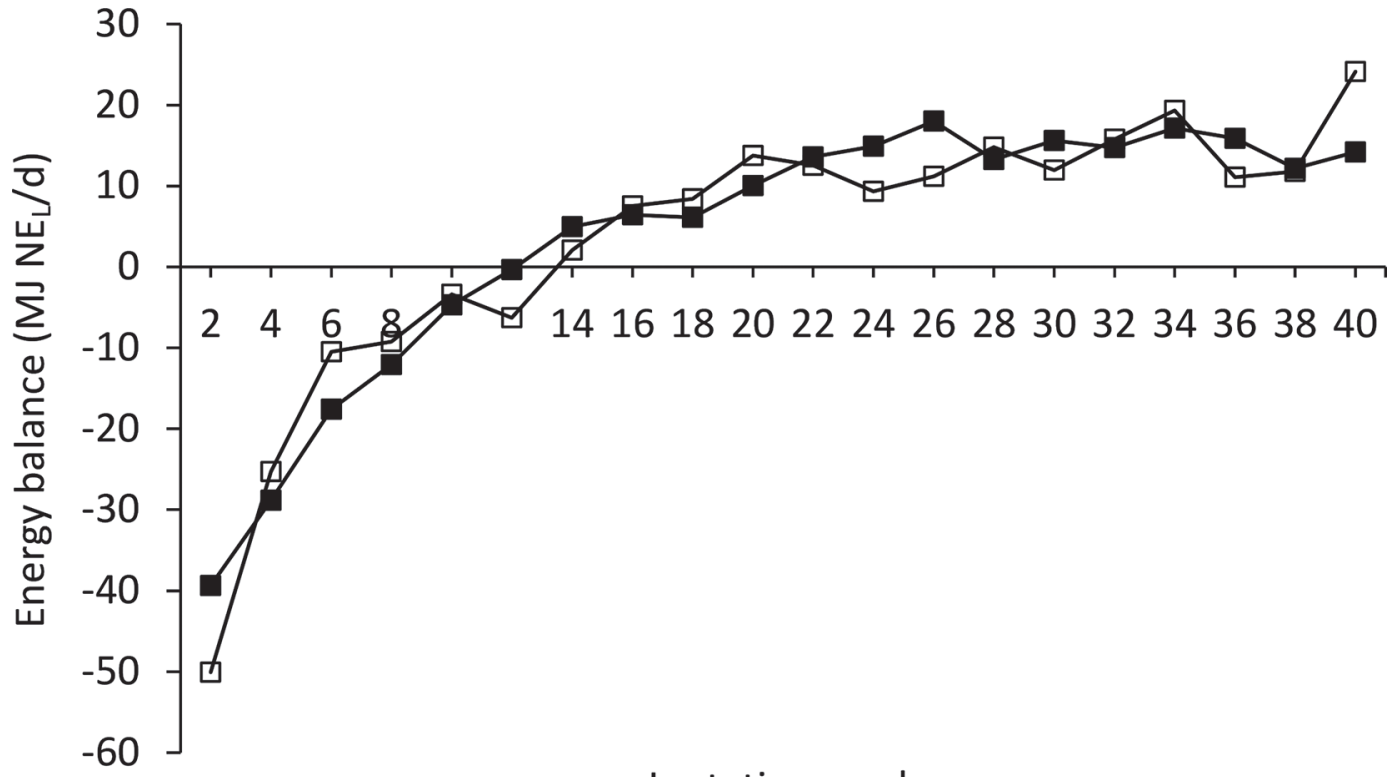

\section{Lactation week}

Figure 3. Energy balance (MJ of $\mathrm{NE}_{\mathrm{L}}$ per d) presented as LSM, per lactation week for multiparous cows fed a daily ration of up to $6 \mathrm{~kg}$ of concentrate (filled; $\mathrm{n}=27$ ) or up to $12 \mathrm{~kg}$ of concentrate (open; $\mathrm{n}=10$ ). The concentrate was byproduct based and fed together with highquality forage ad libitum.

BW change, BCS change, and EB. However, the more positive EB of Holstein cows than SR cows was not reflected by corresponding changes of BW or BCS.

Cows on the $12 \mathrm{kgConc}$ diet had higher BW and BCS than cows on the $6 \mathrm{kgConc}$ diet. However, the $12 \mathrm{kgConc}$ cows were already much heavier and had much higher BCS than $6 \mathrm{kgConc}$ cows in lactation wk 1, before any effect of diet could have emerged. This effect could have been avoided if we had blocked the animals by BW or BCS when assigning treatments before the start of the study.
Low RFI indicates more efficient production, whereas high values of the efficiency measures $\mathrm{ECM} / \mathrm{NE}_{\text {intake }}$ and ECM/DMI are desirable. We observed no differences between diets over the whole lactation in RFI, $\mathrm{ECM} / \mathrm{NE}_{\text {intake, }}$, and ECM/DMI. This is in agreement with previous findings of no effect of diet on ECM/ DMI (Kuoppala et al., 2008; Aguerre et al., 2011; Potts et al., 2015) or RFI (Potts et al., 2015). Others have reported a tendency for lower efficiency, expressed as ECM/DMI, with more concentrate in the diet (Randby et al., 2012; Olijhoek et al., 2018), although with no ef-

Table 6. Blood plasma concentrations of glucose, insulin, nonesterified fatty acids (NEFA), BHB, and IGF-1 during lactation wk 2, 4, 6 , and 20 of multiparous dairy cows fed a daily ration of up to $6 \mathrm{~kg}$ of concentrate (6kgConc) or up to $12 \mathrm{~kg}$ of concentrate (12kgConc), and of Holstein or Swedish Red (SR) breed, presented as LSM with SEM and $P$-value

\begin{tabular}{|c|c|c|c|c|c|c|c|c|c|}
\hline Item & Obs. & \multicolumn{2}{|c|}{ Diet } & $\mathrm{SEM}^{1}$ & $P$-value & \multicolumn{2}{|c|}{ Breed } & SEM & $P$-value \\
\hline Number of cows ${ }^{2}$ & - & 27 & 10 & - & - & 13 & 24 & - & - \\
\hline Insulin $\left(\log _{10}\right)$ & 144 & -1.04 & -0.76 & 0.059 & 0.01 & -0.78 & -1.02 & 0.064 & 0.02 \\
\hline Insulin antilog $(\mu \mathrm{g} / \mathrm{L})$ & - & 0.09 & 0.17 & - & - & 0.17 & 0.10 & - & - \\
\hline NEFA $\left(\log _{10}\right)$ & 142 & -0.54 & -0.57 & 0.027 & 0.46 & -0.62 & -0.49 & 0.029 & $<0.01$ \\
\hline BHB antilog $(\mathrm{mmol} / \mathrm{L})$ & - & 0.98 & 0.92 & - & - & 0.89 & 1.01 & - & - \\
\hline IGF-1 $\left(\log _{10}\right)$ & 144 & 1.84 & 1.94 & 0.027 & 0.03 & 1.92 & 1.86 & 0.030 & 0.16 \\
\hline IGF-1 antilog (ng/mL) & - & 69.0 & 86.7 & — & - & 83.1 & 72.0 & - & - \\
\hline
\end{tabular}

${ }^{1}$ SEM values are weighted averages to adjust for the unbalanced number of observations (Obs.) for the 2 treatment diets.

${ }^{2}$ The numbers of animals were unbalanced due to a parallel genetic study on the low-concentrate cows. 
fect of breed when comparing Holstein and Jersey cows (Olijhoek et al., 2018). In the present study, SR cows had lower RFI than Holstein cows. One contributing explanation can be that the SR cows had a lower BW than the Holstein cows, as VandeHaar et al. (2016) concluded that smaller cows should have a lower maintenance requirement. Results for both EB and RFI were within the same range. This was expected in a study with no differences in BCS change, since the difference between EB and RFI is that the effect of mobilized and deposed energy is included in RFI, in addition to energy from feed for maintenance and for milk production. Moreover, BCS change, EB, and RFI values were close to zero over the whole lactation, which is important as sustainable feeding regimens should keep animals in optimal body condition for maintenance of health and fertility.

\section{Fertility}

Reproductive measures such as calving interval, time to first insemination and total number of inseminations are greatly influenced by management practices and skilfulness, so more objective measures such as time from calving to CoLA or ovulation and $\mathrm{P} 4$ profiles based on $\mathrm{P} 4$ levels in the milk better reflect the fertility of individual cows (Petersson et al., 2006). We observed no differences between cows that were offered
$12 \mathrm{kgConc}$ or $6 \mathrm{kgConc}$ for any of the fertility variables assessed (Table 7). Most fertility measures only have one observation per cow and lactation, so the 37 cows in the present study were probably too few to achieve statistical power due to dietary differences.

Cows with lower IGF-1 blood plasma concentrations after calving take longer to resume ovulatory cyclicity (Wathes et al., 2007). Here, cows on the $6 \mathrm{kgConc}$ diet had lower levels of IGF-1, but it is not possible to conclude from the data that their reproductive performance was affected, since they had only numerically more days from calving to last insemination, or numerically fewer days to first ovulation, compared with cows on the $12 \mathrm{kgConc}$ diet.

The SR cows had more days before CoLA and a higher proportion of cows classified as late CoLA (commencement of luteal activity after 23 DIM) than the Holstein cows. Generally the SR cows have better fertility than Holsteins (Muuttoranta et al., 2019), but SR cows in the study herd have previously been reported to have poorer fertility than Holstein cows (O'Hara et al., 2016; Andrée O'Hara et al., 2019). In those previous studies, BCS of the SR cows was approximately 0.5 points higher (on a scale of $1-5$ ) than that of the Holstein cows, whereas in the present study the difference was somewhat less pronounced but still significant (BCS in lactation wk 1-12 was SR 3.5 and Holstein $3.2 ; P<0.01)$. High BCS at calving is correlated with

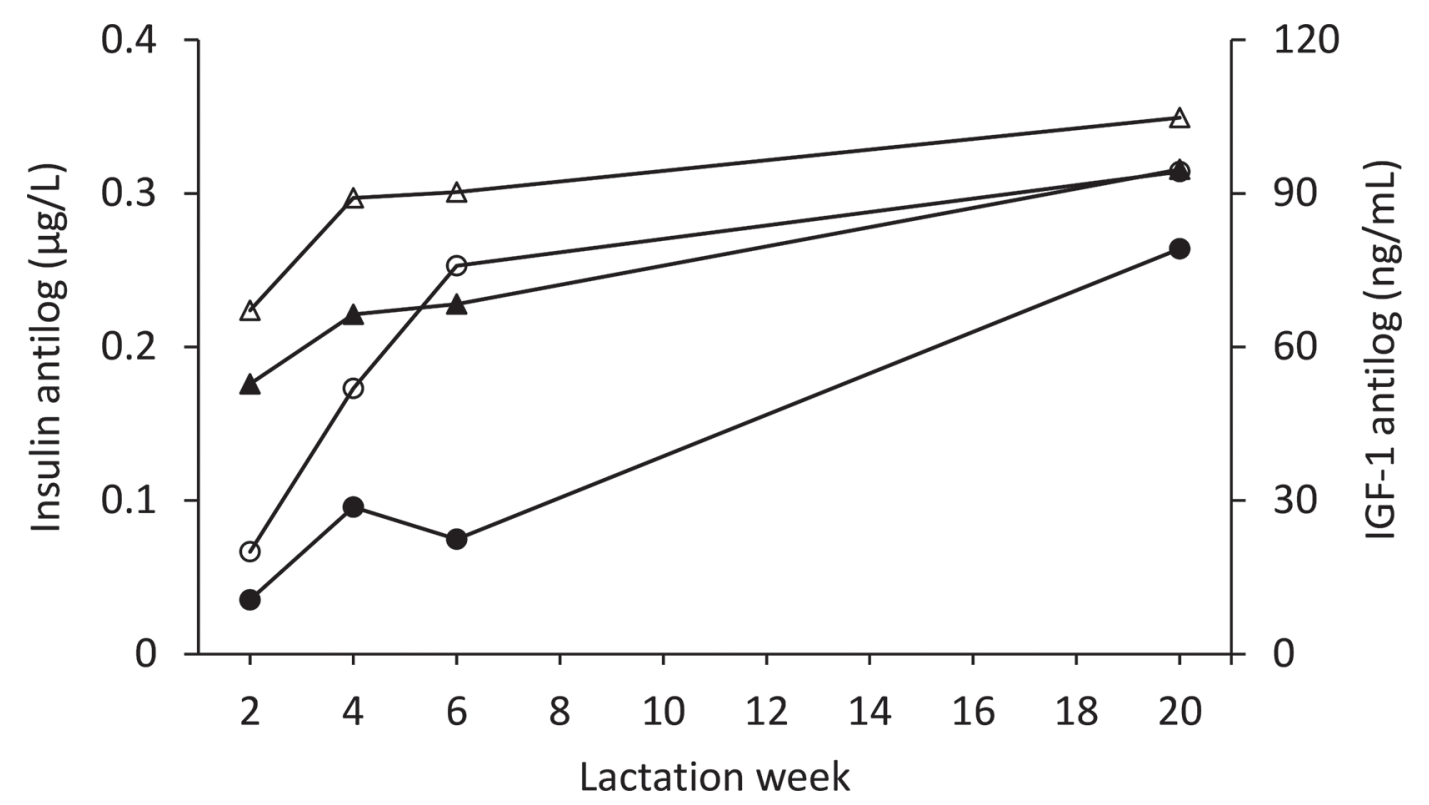

Figure 4. Blood plasma concentrations of insulin (circles) and IGF-1 (triangles), presented as LSM, per lactation week 2, 4, 6, and 20 for multiparous cows fed a daily ration of up to $6 \mathrm{~kg}$ of concentrate (filled; $\mathrm{n}=27$ ) or up to $12 \mathrm{~kg}$ of concentrate (open; $\mathrm{n}=10$ ). The concentrate was byproduct based and fed together with high-quality forage ad libitum. 
poorer reproductive performance (Roche et al., 2009), at least partly explaining the breed difference in fertility measures in the present study.

\section{CONCLUSIONS}

Multiparous Holstein and SR dairy cows were fed high-quality forage ad libitum and a byproduct-based concentrate, virtually without human-grade ingredients, either up to 6 or $12 \mathrm{~kg}$ of concentrate per day during a whole lactation. Cows had a daily mean concentrate intake of 4.24 and $8.34 \mathrm{~kg}$ of $\mathrm{DM}$ over the whole lactation for $6 \mathrm{kgConc}$ and $12 \mathrm{kgConc}$ diet, respectively. We found no significant difference in milk production between cows on different diets. Cows offered $6 \mathrm{kgConc}$ had lower DM and energy intake, but managed to maintain body condition and $\mathrm{EB}$ with a numerical reduction in milk production of $2.4 \mathrm{~kg}$ of ECM yield compared with cows offered $12 \mathrm{kgConc}$. The present study lacked the statistical power to identify treatment effects on daily yield below $2.8 \mathrm{~kg}$ of milk due to low number of animals per treatment. We observed no dietary effect on fertility measures, which again could be the result of a low number of animals per treatment. These results indicate that high milk yields are feasible for cows on high-forage diets with high-digestibility grass-clover silages, not only in cows in early lactation fed grain-based concentrates, but also in cows fed byproduct-based concentrates and over the whole lactation. The cows in the present study managed to adapt to a high-forage diet virtually without human-grade ingredients, without compromising feed efficiency and EB, thereby contributing to sustainable food production.

\section{ACKNOWLEDGMENTS}

This research was included in the research program AquaAgri, which was jointly funded by Formas (Stockholm, Sweden), Mistra (Stockholm, Sweden), and Lantmännen (Stockholm, Sweden), along with funding from Formas (Stockholm, Sweden) and the Swedish Farmers' Foundation for Agricultural Research (Stockholm, Sweden). We thank the staff at the Swedish Livestock Research Centre (Uppsala, Sweden) for managing the animals, the laboratory staff at the Department of Animal Nutrition and Management (SLU, Uppsala, Sweden) for the laboratory analyses, Lantmännen Lantbruk (Malmö, Sweden) for manufacturing the concentrates, and SLU Ultuna egendom (Uppsala, Sweden) for pro-

Table 7. Fertility data for multiparous dairy cows fed a daily ration of up to $6 \mathrm{~kg}$ of concentrate (6kgConc) or up to $12 \mathrm{~kg}$ of concentrate $(12 \mathrm{kgConc})$, and of Holstein or Swedish Red (SR) breed ${ }^{1}$

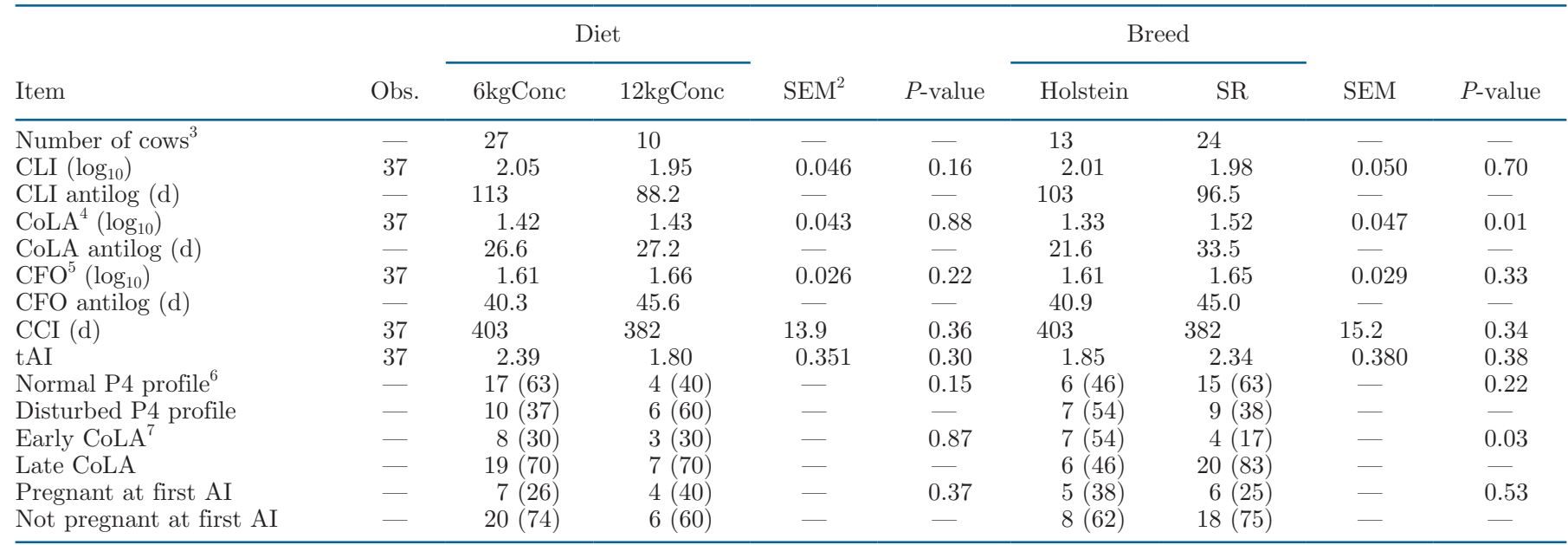

${ }^{1}$ Continuous fertility data [days from calving to last insemination (CLI), days from calving to commencement of luteal activity (CoLA), days from calving to first ovulation (CFO), days from calving to next calving (CCI), and total number of inseminations (tAI)] presented as LSM with SEM and $P$-value. Binominal fertility data [progesterone $(\mathrm{P} 4)$ profiles, early or late for CoLA, and pregnant at first AI] presented as distributions, with percentage within diet in parentheses, and $P$-value.

${ }^{2} \mathrm{SEM}$ values are weighted averages to adjust for the unbalanced number of observations (Obs.) for the 2 treatment diets.

${ }^{3}$ The numbers of animals were unbalanced due to a parallel genetic study on the low-concentrate cows.

${ }^{4}$ Milk P4 above $5 \mathrm{ng} / \mathrm{mL}$.

${ }^{5}$ Milk P4 below $5 \mathrm{ng} / \mathrm{mL}$ after first CoLA.

${ }^{6}$ Classification of normal and disturbed P4 profiles according to Petersson et al. (2006).

${ }^{7}$ Early CoLA $=$ commencement of luteal activity before 23 DIM. Late CoLA = commencement of luteal activity after 23 DIM. 
ducing the silage. We also thank the staff at the Unit of Applied Statistics and Mathematics, Department of Energy and Technology (SLU, Uppsala, Sweden) and Cecilia Kronqvist at the Department of Animal Nutrition and Management (SLU, Uppsala, Sweden) for statistical advice and SAS support. The authors have not stated any conflicts of interest.

\section{REFERENCES}

Adewuyi, A. A., E. Gruys, and F. J. C. M. van Eerdenburg. 2005. Non esterified fatty acids (NEFA) in dairy cattle. A review. Vet. Q. 27:117-126. https://doi.org/10.1080/01652176.2005.9695192.

Agnew, K. W., C. S. Mayne, and J. G. Doherty. 1996. An examination of the effect of method and level of concentrate feeding on milk production in dairy cows offered a grass silage-based diet. Anim. Sci. 63:21-31. https://doi.org/10.1017/S1357729800028241.

Aguerre, M. J., M. A. Wattiaux, J. M. Powell, G. A. Broderick, and C. Arndt. 2011. Effect of forage-to-concentrate ratio in dairy cow diets on emission of methane, carbon dioxide, and ammonia, lactation performance, and manure excretion. J. Dairy Sci. 94:30813093. https://doi.org/10.3168/jds.2010-4011.

Åkerlind, M., and H. Volden. 2011. Standard feed value. Pages 137139 in NorFor-The Nordic Feed Evaluation System. Vol. 130. H. Volden, ed. Wageningen Academic Publishers, Wageningen, the Netherlands. https://doi.org/10.3920/978-90-8686-718-9.

Åkerlind, M., M. Weisbjerg, T. Eriksson, P. Udén, B. L. Ólafsson, O. Harstad, and H. Volden. 2011. Feed analyses and digestion methods. Pages 41-54 in NorFor-The Nordic Feed Evaluation System. Vol. 130. H. Volden, ed. Wageningen Academic Publishers, Wageningen, the Netherlands. https://doi.org/10.3920/978-90-8686 $-718-9$.

Andersen, J. B., N. C. Friggens, T. Larsen, M. Vestergaard, and K. L. Ingvartsen. 2004. Effect of energy density in the diet and milking frequency on plasma metabolites and hormones in early lactation dairy cows. J. Vet. Med. A Physiol. Pathol. Clin. Med. 51:52-57. https://doi.org/10.1111/j.1439-0442.2004.00605.x.

Andersen, J. B., N. C. Friggens, K. Sejrsen, M. T. Sørensen, L. Munksgaard, and K. L. Ingvartsen. 2003. The effects of low vs. high concentrate level in the diet on performance in cows milked two or three times daily in early lactation. Livest. Prod. Sci. 81:119-128. https://doi.org/10.1016/S0301-6226(02)00303-2.

Andrée O'Hara, E., R. Båge, U. Emanuelson, and K. Holtenius. 2019. Effects of dry period length on metabolic status, fertility, udder health, and colostrum production in 2 cow breeds. J. Dairy Sci. 102:595-606. https://doi.org/10.3168/jds.2018-14873.

Andrée O'Hara, E., A. Omazic, I. Olsson, R. Båge, U. Emanuelson, and K. Holtenius. 2018. Effects of dry period length on milk production and energy balance in two cow breeds. Animal 12:508-514. https://doi.org/10.1017/S1751731117001987.

Beecher, M., F. Buckley, S. M. Waters, T. M. Boland, D. EnriquezHidalgo, M. H. Deighton, M. O'Donovan, and E. Lewis. 2014. Gastrointestinal tract size, total-tract digestibility, and rumen microflora in different dairy cow genotypes. J. Dairy Sci. 97:3906-3917. https://doi.org/10.3168/jds.2013-7708.

Bines, J. A., and I. C. Hart. 1984. The response of plasma insulin and other hormones to intraruminal infusion of VFA mixtures in cattle. Can. J. Anim. Sci. 64:304-305. https://doi.org/10.4141/ cjas84-272.

Butler, S. T., A. L. Marr, S. H. Pelton, R. P. Radcliff, M. C. Lucy, and W. R. Butler. 2003. Insulin restores GH responsiveness during lactation-induced negative energy balance in dairy cattle: effects on expression of IGF-I and GH receptor 1A. J. Endocrinol. 176:205-217. https://doi.org/10.1677/joe.0.1760205.

Chai, W. H., and P. Udén. 1998. An alternative oven method combined with different detergent strengths in the analysis of neutral detergent fibre. Anim. Feed Sci. Technol. 74:281-288. https://doi .org/10.1016/S0377-8401(98)00187-4.

EC. 2009. Commission regulation (EC) No 152/2009 of 27 January 2009 laying down the methods of sampling and analysis for the official control of feed. Off. J. Eur. Union L 54:1-130. https:// eur-lex.europa.eu/legal-content/EN/TXT/PDF/?uri=CELEX: 32009R0152\&from $=\mathrm{EN}$.

Emanuelson, M., C. Cederberg, J. Bertilsson, and H. Rietz. 2006. Locally grown feeds for dairy cows - a knowledge update [in Swedish]. Swedish Dairy Association, Stockholm, Sweden.

Ertl, P., Q. Zebeli, W. Zollitsch, and W. Knaus. 2016. Feeding of wheat bran and sugar beet pulp as sole supplements in high-forage diets emphasizes the potential of dairy cattle for human food supply. J. Dairy Sci. 99:1228-1236. https://doi.org/10.3168/jds.2015 -10285 .

FAO. 2014. World mapping of animal feeding systems in the dairy sector. FAO, Rome, Italy.

Faverdin, P., J. P. Dulphy, J. B. Coulon, R. Vérité, J. P. Garel, J. Rouel, and B. Marquis. 1991. Substitution of roughage by concentrates for dairy cows. Livest. Prod. Sci. 27:137-156. https://doi .org/10.1016/0301-6226(91)90092-5.

Ferris, C. P., F. J. Gordon, D. C. Patterson, D. J. Kilpatrick, C S. Mayne, and M. A. McCoy. 2001. The response of dairy cows of high genetic merit to increasing proportion of concentrate in the diet with a high and medium feed value silage. J. Agric. Sci. 136:319-329. https://doi.org/10.1017/S002185960100870X.

Gross, J., H. A. van Dorland, R. M. Bruckmaier, and F. J. Schwarz. 2011. Milk fatty acid profile related to energy balance in dairy cows. J. Dairy Res. 78:479-488. https://doi.org/10.1017/ S0022029911000550.

Hristov, A. N., A. Bannink, L. A. Crompton, P. Huhtanen, M. Kreuzer, M. McGee, P. Nozière, C. K. Reynolds, A. R. Bayat, D. R. Yáñez-Ruiz, J. Dijkstra, E. Kebreab, A. Schwarm, K. J. Shingfield, and Z. Yu. 2019. Invited review: Nitrogen in ruminant nutrition: A review of measurement techniques. J. Dairy Sci. 102:5811-5852. https://doi.org/10.3168/jds.2018-15829.

Huhtanen, P. 1993. The effects of concentrate energy source and protein content on milk production in cows given grass silage ad libitum. Grass Forage Sci. 48:347-355. https://doi.org/10.1111/j.1365 -2494.1993.tb01868.x.

Huhtanen, P., S. Jaakkola, and E. Saarisalo. 1995. The effects of concentrate energy source on the milk production of dairy cows given a grass silage-based diet. Anim. Sci. 60:31-40. https://doi.org/10 $.1017 /$ S1357729800008109.

IPCC. 2019. Climate Change and Land: an IPCC special report on climate change, desertification, land degradation, sustainable land management, food security, and greenhouse gas fluxes in terrestrial ecosystems. Intergovernmental panel on climate change. Accessed Nov. 5, 2019. https://www.ipcc.ch/site/assets/uploads/2019/08/ Fullreport-1.pdf.

Jarrige, R., C. Demarquilly, J. P. Dulphy, A. Hoden, J. Robelin, C. Beranger, Y. Geay, M. Journet, C. Malterre, D. Micol, and M. Petit. 1986. The INRA "Fill Unit" system for predicting the voluntary intake of forage-based diets in ruminants: A review. J. Anim. Sci. 63:1737-1758. https://doi.org/10.2527/jas1986.6361737x.

Karlsson, J., R. Spörndly, M. Lindberg, and K. Holtenius. 2018. Replacing human-edible feed ingredients with by-products increases net food production efficiency in dairy cows. J. Dairy Sci. 101:7146-7155. https://doi.org/10.3168/jds.2017-14209.

Kuoppala, K., M. Rinne, J. Nousiainen, and P. Huhtanen. 2008. The effect of cutting time of grass silage in primary growth and regrowth and the interactions between silage quality and concentrate level on milk production of dairy cows. Livest. Sci. 116:171-182. https://doi.org/10.1016/j.livsci.2007.10.002.

Kuoppala, K., S. Yrjänen, S. Jaakkola, R. Kangasniemi, J. Sariola, and H. Khalili. 2004. Effects of increasing concentrate energy supply on the performance of loose-housed dairy cows fed grass silage-based diets. Livest. Prod. Sci. 85:15-26. https://doi.org/10.1016/S0301 -6226(03)00119-2. 
Larsson, K., and S. Bengtsson. 1983. Determination of non-structural carbohydrates in plant material [in Swedish]. Method description n. 22. National Laboratory for Agricultural Chemistry, Uppsala, Sweden.

Lawrence, D. C., M. O'Donovan, T. M. Boland, E. Lewis, and E. Kennedy. 2015. The effect of concentrate feeding amount and feeding strategy on milk production, dry matter intake, and energy partitioning of autumn-calving Holstein-Friesian cows. J. Dairy Sci. 98:338-348. https://doi.org/10.3168/jds.2014-7905.

Li, B., W. F. Fikse, P. Løvendahl, J. Lassen, M. H. Lidauer, P. Mäntysaari, and B. Berglund. 2018. Genetic heterogeneity of feed intake, energy-corrected milk, and body weight across lactation in primiparous Holstein, Nordic Red, and Jersey cows. J. Dairy Sci. 101:10011-10021. https://doi.org/10.3168/jds.2018-14611.

Lindgren, E. 1979. The nutritional value of roughages determined in vivo and by laboratory methods. Report 45 . Department of animal nutrition, Swedish University of Agricultural Sciences, Uppsala, Sweden.

Lindgren, E. 1983. New calibration of the VOS-method to estimate energy value of forage. Department of Animal Nutrition and Management, Swedish University of Agricultural Sciences, Uppsala, Sweden [In Swedish].

Mehtiö, T., M. Rinne, L. Nyholm, P. Mäntysaari, A. Sairanen, E. A. Mäntysaari, T. Pitkänen, and M. H. Lidauer. 2016. Cow-specific diet digestibility predictions based on near-infrared reflectance spectroscopy scans of faecal samples. J. Anim. Breed. Genet. 133:115-125. https://doi.org/10.1111/jbg.12183.

Morris, D. L., L. R. Rebelo, P. A. Dieter, and C. Lee. 2018. Validating intrinsic markers and optimizing spot sampling frequency to estimate fecal outputs. J. Dairy Sci. 101:7980-7989. https://doi.org/ 10.3168/jds.2018-14717.

Muuttoranta, K., A.-M. Tyrisevä, E. A. Mäntysaari, J. Pösö, G. Pedersen Aamand, and M. H. Lidauer. 2019. Genetic parameters for female fertility in Nordic Holstein and Red Cattle dairy breeds. J. Dairy Sci. 102:8184-8196. https://doi.org/10.3168/jds.2018-15858.

Neveu, C., B. Baurhoo, and A. Mustafa. 2013. Effect of feeding extruded flaxseed with different forage:concentrate ratios on the performance of dairy cows. J. Dairy Sci. 96:3886-3894. https://doi .org/10.3168/jds.2012-6189.

Ntallaris, T., P. Humblot, R. Båge, Y. Sjunnesson, J. Dupont, and B. Berglund. 2017. Effect of energy balance profiles on metabolic and reproductive response in Holstein and Swedish Red cows. Theriogenology 90:276-283. https://doi.org/10.1016/j.theriogenology .2016 .12 .012

Nyman, A.-K., U. Emanuelson, K. Holtenius, K. L. Ingvartsen, T. Larsen, and K. Persson Waller. 2008. Metabolites and immune variables associated with somatic cell counts of primiparous dairy cows. J. Dairy Sci. 91:2996-3009. https://doi.org/10.3168/jds.2007 -0969 .

O'Hara, L. A., R. Båge, and K. Holtenius. 2016. The impact of body condition after calving on metabolism and milk progesterone profiles in two breeds of dairy cows. Acta Vet. Scand. 58(Suppl 1):68. https://doi.org/10.1186/s13028-016-0251-2.

Olijhoek, D. W., P. Løvendahl, J. Lassen, A. L. F. Hellwing, J. K. Höglund, M. R. Weisbjerg, S. J. Noel, F. McLean, O. Højberg, and P. Lund. 2018. Methane production, rumen fermentation, and diet digestibility of Holstein and Jersey dairy cows being divergent in residual feed intake and fed at 2 forage-to-concentrate ratios. J. Dairy Sci. 101:9926-9940. https://doi.org/10.3168/jds.2017-14278.

Palmquist, D. L., C. L. Davis, R. E. Brown, and D. S. Sachan. 1969. Availability and metabolism of various substrates in ruminants. V. Entry rate into the body and incorporation into milk fat of $\mathrm{d}(-)$ $\beta$-hydroxybutyrate. J. Dairy Sci. 52:633-638. https://doi.org/10 .3168/jds.S0022-0302(69)86620-8.

Pang, D., T. Yan, E. Trevisi, and S. J. Krizsan. 2018. Effect of grainor by-product-based concentrate fed with early- or late harvested first-cut grass silage on dairy cow performance. J. Dairy Sci. 101:7133-7145. https://doi.org/10.3168/jds.2018-14449.

Patel, M., E. Wredle, and J. Bertilsson. 2013. Effect of dietary proportion of grass silage on milk fat with emphasis on odd- and branched-chain fatty acids in dairy cows. J. Dairy Sci. 96:390-397. https://doi.org/10.3168/jds.2012-5441.

Patel, M., E. Wredle, E. Spörndly, and J. Bertilsson. 2017. Whole lactation production responses in high-yielding dairy cows using high-quality grass/clover silage. J. Sci. Food Agric. 97:2883-2890. https://doi.org/10.1002/jsfa.8119.

Petersson, K.-J., H. Gustafsson, E. Strandberg, and B. Berglund. 2006. Atypical progesterone profiles and fertility in Swedish dairy cows. J. Dairy Sci. 89:2529-2538. https://doi.org/10.3168/jds .S0022-0302(06)72328-1.

Potts, S. B., J. P. Boerman, A. L. Lock, M. S. Allen, and M. J. VandeHaar. 2015. Residual feed intake is repeatable for lactating Holstein dairy cows fed high and low starch diets. J. Dairy Sci. 98:4735-4747. https://doi.org/10.3168/jds.2014-9019.

Randby, Å. T., M. R. Weisbjerg, P. Nørgaard, and B. Heringstad. 2012. Early lactation feed intake and milk yield responses of dairy cows offered grass silages harvested at early maturity stages. J. Dairy Sci. 95:304-317. https://doi.org/10.3168/jds.2011-4454.

Roche, J. R., N. C. Friggens, J. K. Kay, M. W. Fisher, K. J. Stafford, and D. P. Berry. 2009. Invited review: Body condition score and its association with dairy cow productivity, health, and welfare. J. Dairy Sci. 92:5769-5801. https://doi.org/10.3168/jds.2009-2431.

Rukkwamsuk, T., M. J. H. Geelen, T. A. M. Kruip, and T. Wensing. 2000. Interrelation of fatty acid composition in adipose tissue, serum, and liver of dairy cows during the development of fatty liver postpartum. J. Dairy Sci. 83:52-59. https://doi.org/10.3168/jds .S0022-0302(00)74854-5.

Sjaunja, L. O., L. Baevre, L. Junkkarinen, J. Pedersen, and J. Setälä. 1990. A Nordic proposal for an energy corrected milk (ECM) formula. Pages 156-192 in Performance Recording of Animals: 27th Biennial Session of the International Committee of Animal Recording, Paris, France.

SJVFS. 2011. 2011:40, Saknr M 39. Code of statutes, regulations and common advice concerning feed [in Swedish]. The Swedish Board of Agriculture, Jönköping, Sweden.

Soita, H. W., M. Fehr, D. A. Christensen, and T. Mutsvangwa. 2005. Effects of corn silage particle length and forage:concentrate ratio on milk fatty acid composition in dairy cows fed supplemental flaxseed. J. Dairy Sci. 88:2813-2819. https://doi.org/10.3168/jds .S0022-0302(05)72961-1.

Stoop, W. M., H. Bovenhuis, J. M. L. Heck, and J. A. M. van Arendonk. 2009. Effect of lactation stage and energy status on milk fat composition of Holstein-Friesian cows. J. Dairy Sci. 92:1469-1478. https://doi.org/10.3168/jds.2008-1468.

Strandberg, E., and C. Lundberg. 1991. A note on the estimation of environmental effects on lactation curves. Anim. Prod. 53:399-402. https://doi.org/10.1017/S0003356100020420.

Swensson, C., H. Lindmark-Månsson, A. Smedman, M. Henriksson, and A.-K. Modin Edman. 2017. Protein efficiency in intensive dairy production: A Swedish example. J. Sci. Food Agric. 97:48904897. https://doi.org/10.1002/jsfa.8362.

Thorup, V. M., D. Edwards, and N. C. Friggens. 2012. On-farm estimation of energy balance in dairy cows using only frequent body weight measurements and body condition score. J. Dairy Sci 95:1784-1793. https://doi.org/10.3168/jds.2011-4631.

Van Keulen, J., and B. A. Young. 1977. Evaluation of acid-insoluble ash as a natural marker in ruminant digestibility studies. J. Anim. Sci. 44:282-287. https://doi.org/10.2527/jas1977.442282x.

Van Soest, P. J. 1994. Nutritional Ecology of the Ruminant. Cornell University Press, Ithaca, NY.

Van Zanten, H. H. E., M. K. Van Ittersum, and I. J. M. De Boer. 2019. The role of farm animals in a circular food system. Glob. Food Secur. 21:18-22. https://doi.org/10.1016/j.gfs.2019.06.003.

VandeHaar, M. J., L. E. Armentano, K. Weigel, D. M. Spurlock, R. J. Tempelman, and R. Veerkamp. 2016. Harnessing the genetics of the modern dairy cow to continue improvements in feed efficiency. J. Dairy Sci. 99:4941-4954. https://doi.org/10.3168/jds .2015-10352.

Växa Sverige. 2018. Cattle statistics 2018. Växa Sverige, Uppsala, Sweden. 
Volden, H., and N. I. Nielsen. 2011. Energy and metabolizable protein supply. Pages 81-84 in NorFor - the Nordic feed evaluation system. Vol. 130. H. Volden, ed. Wageningen Academic Publishers, Wageningen, the Netherlands. https://doi.org/10.3920/978-90 -8686-718-9.

Wathes, D. C., M. Fenwick, Z. Cheng, N. Bourne, S. Llewellyn, D. G. Morris, D. Kenny, J. Murphy, and R. Fitzpatrick. 2007. Influence of negative energy balance on cyclicity and fertility in the high producing dairy cow. Theriogenology 68:S232-S241. https://doi .org/10.1016/j.theriogenology.2007.04.006.

Weißhuhn, P., M. Reckling, U. Stachow, and H. Wiggering. 2017. Supporting agricultural ecosystem services through the integration of perennial polycultures into crop rotations. Sustainability 9:2267. https://doi.org/10.3390/su9122267.

\section{ORCIDS}

Johanna Karlsson @ \ttps://orcid.org/0000-0002-2987-8330

Mikaela Lindberg @ $\odot$ https://orcid.org/0000-0001-7299-4276

Maria Åkerlind ๑ https://orcid.org/0000-0002-3538-7036

Kjell Holtenius (ํ) https://orcid.org/0000-0003-1739-263X 